\title{
An intervention designed to improve sensory impairments in the elderly and indoor lighting in their homes: an exploratory randomized controlled trial [Corrigendum]
}

\author{
Haanes GG, Kirkevold M, Hofoss D, Horgen G, Eilertsen G. \\ J Multidiscip Healthc. 2015;8:11-20. \\ On page 15, Visual status heading, the first sentence "The \\ results from the vision test are presented in Table 3" should \\ have been removed from the paper. The second sentence \\ should have read "There were some slight improvements in \\ the VA in both groups between $\mathrm{T}_{1}$ and $\mathrm{T}_{2}$; these improvements \\ did not differ significantly between the groups (one-way \\ ANOVA between the groups, $P=0.57$ )."
}

On page 16, Hearing status heading, the first sentence "The results from the pure-tone audiometry test are presented in Table 4" should have been removed from the paper.

\section{Publish your work in this journal}

The Journal of Multidisciplinary Healthcare is an international, peerreviewed open-access journal that aims to represent and publish research in healthcare areas delivered by practitioners of different disciplines. This includes studies and reviews conducted by multidisciplinary teams as well as research which evaluates the results or conduct of such teams or healthcare processes in general. The journal covers a wide range of areas and welcomes submissions from practitioners at all levels, from all over the world. The manuscript management system is completely online and includes a very quick and fair peer-review system. Visit http://www.dovepress.com/testimonials.php to read real quotes from published authors. 